\title{
Enhancement of Audit Quality Through Audit Firm Rotation (Case Study Selected Commercial Banks in Ethiopia)
}

\author{
Ismael Hussein Malela \\ Lecturer, Bonga University, CBE, Department of Accounting and finance
}

\begin{abstract}
The purpose of this study is to examine the Audit Firm Rotation and Audit Quality using Evidence from selected Ethiopia Commercial Banks in Addis Abeba, Ethiopia. The main objective of the study is to examine the extent that audit firm rotation significantly affects audit quality, and to evaluate the relationship between board independence and audit quality. The possibility of enhancing audit quality through audit firm rotation is a key method used by regulatory body. This study intended to assess the applicability of the mandatory auditor rotation concept in the Ethiopian banking sector so as to enhance and improve audit quality, from the findings of both the literature as well as the field survey, it was discovered that audit firm rotation significantly affect audit quality. It was concluded that rotation is a good solution to enhance Audit quality and also to maintain the auditor independence by decreasing the audit firm's dependence on the client. Recommendations were made based on the findings that the regulatory bodies such as National Bank of Ethiopia, Federal Auditor General should make a laws that will appreciate audit firm rotation in order to improve audit quality, also the National Bank of Ethiopia should think of possible other ways of addressing the concept of audit quality.
\end{abstract}

Keywords: Audit Quality, Audit Firm Rotation, Audit Fee, National Bank of Ethiopia.

DOI: $10.7176 /$ RJFA/11-1-04

Publication date: January $31^{\text {st }} 2020$

\section{Background of the Study}

The issue of Audit quality has attracted enormous attention since the financial reporting mis-representation and falsification of data stared in major world corporations like Enron and World Com in the United State of America as well as Parallax in Italy. It is defined as the auditor's ability to discover a breach in the client's accounting system combined with the auditor's willingness to report such breach (Deangelo, 1981; Watts \& Zimmerman, 1981). Riyatno (2007), defines audit quality as something that is abstract, difficult to measure and can only be perceived by the users of audit services. Thus, there is no uniform definition of audit quality. While Dc Angelo (1981) as cited in Ibrahim (2001) defines audit quality as the combined probability to detect and report material errors in financial statements, Pawulos (2002) defines audit quality in terms of the level of assurance since the purpose of an audit is to provide reasonable assurance to users on financial statements.

The 2006 EC the where a core banking system agreement among all commercial banks in Ethiopia, and this consolidation of banking sector in Ethiopian brought about the introduction of mandatory audit firm rotation as part of banks' code of corporate governance with the aim of further strengthening audit quality. Mandatory audit firm rotation became topical after the simultaneous speech of 8 banks chiefs by the governor of National Bank of Ethiopia in $2007 \mathrm{EC}$, and the imposition of external auditors rotation after 10 years of engagement by the national bank. It was also said by the national bank that for the avoidance of doubt, the maximum period of 10 years shall include the period an audit firm that started new era for banking sector in Ethiopia.

Mandatory rotation of external auditors requires audit firms to be rotated after a specified number of years irrespective of the quality, independence of the audit firm, the willingness of the shareholders and the management to keep the firm. Anteneh, D (2011) in his research agreed that that audit firm rotation improves audit objectivity and that long-term relationships between companies and their auditors tends to reduce auditors' independence and quality and According to Hayle, (2010) a client maybe a significant source of revenue for an auditor and the auditor may be reluctant to jeopardize the revenue stream as he would not want to miss the money that feeds him. The audit quality is also diminished with long term audit tenure, so that mandatory firm rotation will reduce the familiarity threat, ensures auditors independence and provides a greater skepticism and a fresh perspective that may be lacking in long-standing audit or client relationship Jackson (2013)

\subsection{Statement of Problem}

There are many different privies studies (Arrunada \& Paz-Ares, 2007; Brody \& Mokenin, 2010; Dopuch, King \& Schwartz, 2011; Musa \& Omer, 2013) have tried to examine possible explanatory variables for the state of audit quality. The presence of audit failures in the world has brought a great deal of disappointment to stakeholders and investors, and the longness of audit firm tenure has also been linked with fraudulent financial reporting which can be reduced by the audit firm rotation and improves audit quality as auditors may need to be experts in their area and acquire client-specific knowledge overtime (Ghosh \& Moon, 2011; Defond \& Francis, 2005; Jenkins \& Velury, 2014). This means that audit quality is lower during the early years of the auditor-client relationship and increases 
with length of audit firm rotation due to the reduction in information communication between auditor and client (Aziza, Mokenin \& Sheba, 2016).

Therefore, this study extends and contributes to the body of research using data from Ethiopian banking sector by investigating the enhancement of Audit Quality through audit firm rotation.

\subsection{Research Questions}

For this study the following four basic research questions are considered:

1. To what extent does audit firm rotation significantly affect audit quality?

2. Is there any relationship between company size and audit quality?

3. How do audit fees affect audit quality?

4. What is the relationship between board independence and audit quality?

\subsection{Objectives of the Study}

The general objective of this study is to examine the enhancement of audit quality through audit firm rotation. The specific objectives of the study are as follows

To examine the extent that audit firm rotation significantly affects audit quality;

To determine the relationship between company size and audit quality;

To investigate how audit fees affects audit quality; and

To evaluate the relationship between board independence and audit quality.

\subsection{Research Hypotheses}

The hypotheses stated below are raised in order to achieve the specific objectives of this study.

\section{Hypothesis one}

HO: Audit firm rotation contributes negatively to the quality of audit assignment.

HI: Audit firm rotation contributes positively to the quality of audit assignment.

\section{Hypothesis two}

HO: There is no significant relationship between the firm's size and audit quality.

HI: There is significant relationship between the firm's size and audit quality.

\section{Hypothesis three}

HO: There is no significant relationship between board independence and audit quality.

HI: There is significant relationship between board independence and audit quality.

\section{Hypothesis four}

HO: There is no significant relationship between affecting audit quality.

HI: There is significant relationship between affecting audit quality.

\subsection{Limitation of the Study}

Since this study focused on Ethiopia banks, the findings may not be applicable to other companies in a different sector because of the individual characteristics and behaviors of different industries or sectors.

\section{Review of Related Literature}

In this chapter both theoretical literature review and empirical literature reviews are considered.

\subsection{The Concept of Audit Quality}

Auditing is the activity carried on by the auditor when he verifies accounting data determines the accuracy and reliability of accounting statements and then reports on his findings. It is basically an activity carried on by an independent person with the aim of reporting on the true and fairness of financial statements (Mill champ, 1994). Auditing of financial statement is the systematic process of objectively obtaining and evaluating evidence regarding assertions about economic actions and events to ascertain the degree of correspondence between these assertions and established criteria and communicating the results to interested users (Gramling, Ritten berg \& John stone, 2010). In essence, auditing is used to provide the needed reasonable assurance for financial statement users who rely on audited financial statements. Furthermore, the role of auditing is to reduce the information gap on accounting numbers and to decrease the loss due to the managers' discretion in financial reporting.

According to Royalton (2007), audit quality is something that is abstract, difficult to measure and can only be perceived by the users of audit services so that until now there is no uniform definition of audit quality. Wallace (1980) also notes that a measure of audit quality is the audit's ability to reduce noise, bias and improve the quality in accounting information. As noted by Levitt (2000), the perception of audit quality plays a critical role in maintaining systematic confidence in the integrity. Of financial reporting. The higher the perceived audit quality, the more credible the financial statements. Moidrich, Jackson and Roebuck (2007) posit that true audit quality is when the audit does not result in a type 1 error(a failing company being given an unqualified report) or a type II 
error(a non- failing company being given a qualified report). Audit quality is characterized by some of the following characteristics as posited by Yamane (2011).

Significance: This portrays the relevance of the matter that is being examined in the audit. This can be measured by using the financial size of the auditee and the performance effects that the auditee has on the public

Reliability: The audit findings and conclusions with respect to the matter being examined. The audit reports are measured to know if they can be reliable.

Objectively: The audit will be checked to know if it is carried out in an impartial and fair manner without favor or bias. The auditor is expected to prepare and present his report and opinion purely on fact and on sound analysis.

Scope: The task plan and execution of the audit must satisfactorily cover all areas.

Timeliness: The time the results are delivered is also important because it also affect audit quality. The results should be presented when it is most useful in correcting management weaknesses.

Clarity: The audit report must be clear enough for others not in the field to still understand the message being passed across.

Efficiency: The distribution of the resources has to be assigned to the audit reasonably in the light of the significance and complexity of the audit.

\subsection{Audit Quality and Audit Firm Rotation}

The idea of auditor rotation was first introduced and discussed in 1976 (Hoyle 1986). It is classified into mandatory or voluntary rotation. The mandatory rotation makes it compulsory for firms to change their auditors after a fixed duration $(\mathrm{Lu}, 2005)$ while the voluntary rotation is optional. Mandatory rotation could be either through the audit firm rotation which requires listed companies to change or rotate their CPA firms after a specific period of time or through the audit partner rotation which requires audit firms to change or rotate the audit lead partner who is in charge of an audit client after a specific period of time instead of the whole CPA firm (Arel, Richard, Brody\& Pany, 2005; Orin, 2008). Voluntary rotation is mainly based on the management decisions and choice regardless of time to change their auditor. This decision may be due to factors other than compulsion by regulatory authorities. Over the years, mandatory audit firm rotation has been examined by many authors, some have supported it while others opposed. Arguments supporting audit firm rotation include: Reborn (2006) who asserts that it might provide smaller audit firms the opportunity to participate and earn income due to increasing market competition. They also noted that mandatory rotation causes improvement in the work of an audit firm since it knows its work will be reviewed by another audit firm when they are rotated after a specific period of time (Davis, 2008). It is also argued that rotation provides new insight to the client's financial statements. Since the auditing practice is based on employing professional skepticism and the short term client auditor relationship can reduce the sharpness of his judgment (Wolf, 1999; Nagy, 2005). According to Lu (2005), audit rotation ensures innovativeness. This means that it makes people not in the profession to know what it entails and embraces new things that will improve the profession. Finally, it has been observed that both auditors and clients suffer great losses in cases of audit failures. Although, there is associated cost when rotating auditors, this cost however is less than the cost of excessive litigation and loss of reputation due to such audit failures.

A long auditor- client relationship could lead to an alignment of the auditor's interest and that of its client which makes the supposed independent behavior of the auditor to be doubted. The study concluded that audit firm rotation does not enhance audit independence in Ethiopia. This could be due to the unity of professional attitude among auditors. Eba and Oliyad (2013) argued that auditors that are engaged in a long term relationship may signal skepticism with regards to the perception of the auditor's objectively, independence and audit quality. The study concludes that a policy favoring mandatory rotation of auditors could have positive effects on the quality of audit reports as it would allow for fresh insight and restore public confidence in the audit function.

Nashwa (2004) work did not support that mandatory rotation improves audit quality. He attempted to verify the association between a long tenure auditor client -relationship and audit failures. The collected data showed that failure occurs more frequently in the first 3 years and in 7 or more of audit tenure. Furthermore, the failure rates were computed by relating the number of failures in each tenure class to the total number of audits involving the same period of tenure. To address the issue more deeply, a logistic model was used to predict failure using tenure as the variable. The results indicated that risk increases early in the auditor client relation and then declines overtime. The author concluded that the results of his survey do not support the hypothesis that mandatory rotation improves audit quality.

Chung (2004) observed that audit quality appears to improve when the duration of the auditor- client relationship is truncated. The study examined the impact of limited auditor tenure on earnings and audit quality. Variables of discretionary accruals were used as dependent variables in a cross sectional modified model. The samples consist of data from Korean publicly held companies listed on the Korean Stock Exchange, collected in the 1985-1995 period. The year in which mandatory rotation was enforced in Korea, 1990 was excluded from the sample because it represents a transitional period. Following the auditor's reasoning, a limit on the length of the auditor- client relationship results in greater incentives for auditors to maintain independence. So the firm's 
opportunistic manipulation of earnings is efficiently restricted.

Johnson, Khorana and Reynolds (2002) argued that mandatory rotation may not be the best solution to the issue of audit quality. The study examines whether the length of the relationship between a company and audit firm is associated with financial reporting quality. Audit reports of a sample of US companies entering into bankruptcy during years 1996-1998 were observed. The result indicated that the tenure variable is consistently positive and significant. This conclusion is consistent with the position that auditors may be more influenced in the first year of engagement and it does not support those who propose that the rotation of auditors must be mandatory.

\subsection{Audit Quality and Audit Fees}

There are many reasons adduced to cause a positive relationship between auditor fees and audit quality. Quality investigation and audit procedures will require more audit hours, higher cost due to the use of more experienced and specialized staff and thus, higher audit fees (O'Sullivan, 2000; Ghosh \& Pawlewich, 2008). However, large audit fees paid by the client make the auditor more economically dependent on the client, thus it forces the auditor to be more reluctant in queering the client during the audit for fear of losing the stream of income. After the Sarbanes Oxley Act (SOA 2002), total fees of audit firms have increased indicating that total revenues from audit clients will increase after the rotation decision. This is due to the increased litigation an auditor would be exposed to as a result, the auditor will exert more effort \& time and this will impress on him increasing the audit fees required (Ghosh \& Pawlewich, 2008).

Companies can experience high start-up costs when hiring a new auditor. By working on the same clients for a period of years, auditors can earn client specific quasi- rents that can serve as collateral against opportunistic behavior. Larger auditors have 'more to lose' from supplying a lower than promised level of audit quality and thus have a higher perceived audit quality. De Angelo (1981) also argues that the difference in agency costs indicate a differing 'level of audit quality'.

Audit fee is the fees paid for annual audits and reviews of financial statements for the most recent fiscal year (SEC, Final Rule). Auditor's fees is considered a measure for the assessment of the audit quality, as it is assumed that high audit fees reflects a high quality especially if the audit is performed by a reputable audit firm. Furthermore, there are other factor that point to the correlation of audit fees and audit quality. Firstly, if there are any report adjustments, the auditor is required to accumulate a greater amount of evidence to achieve the same quality, which results in more hours and higher audit fees (Arens \& Loebbecke, 1997). Audit fees can also be affected by location and the complexity/coordination of an engagement. For example, if the client has multiple locations that require visits, the audit fees will be higher. Audit fees can vary with additional reports (Palmrose, 1986). The additional report has to do with the location and the fees that is applicable to other firms. The client's industry can also affect audit fees by measuring differences in risk that the firms will surely have different ways of having risk because they operate in different ways. Audit fees are also generally higher among companies with public ownership. Companies with public ownership are at a greater exposure to risk and thus, require more audit evidence and investigation. All of these variables arguably cause difference in fees between a small and large firm.

According to the Decree of the General Chairman of Indonesian Institute of Certified Public Accountants, setting audit fees requires Public Accountants to consider the following characteristics vs client needs, independence, the level of expertise and responsibility inherent in the work performed, the duties and responsibilities according to law, and the complexity level of the job done. While the Rules of Ethics of Certified Public Accountants Compartment (2001) opines that the amount of fees depends on the following matters: risk assignment, the complexity of services provided, level of expertise required to perform such services and the cost structure of audit firm.

\subsection{Audit Qualities and Company Size}

In view of the global recession of 2009-2010, when investments in banks and financial institutions was unsafe and caused a financial meltdown that required strong input and investment by most democratic governments, the need for internationally regulated and well audited financial institutions have started to concentrate on serious internal audit processes undertaken by an internal audit team that conducts regular control assessments. Small public accounting firms is higher than big public accounting firm. A large number of small firm causes a high level of competition in the acquisition of clients, this require a small firm to pay attention to the appearance of staff.

According to Mustafa (2009), to improve the appearance, quality and image of public accounting investment should be planned and prepared; it causes the firm to leave the lower prices.

\subsection{Audit Quality and Board Independence}

Board independence is also a factor that contributes to audit quality, because research suggests that board independence is negatively related to the likelihood of financial fraud and SEC enforcement actions (Beasley, 1996; Dechow, Sloan \& Sweeney; 1996). While some researchers find that a large board has more expertise than 
a small one(Dalton, Daily, Johnson \& Ellstrand, 1999), that it tends to be more effective in monitoring accrual (Xie, Davidson \& Dadalt, 2003) and that it leads to a lower cost of debt( Anderson, Mansi \& Reeb; 2004). Others suggest that a small board is more effective in mitigating the agency costs associated with a large board (Yermack, 1996; Eisenberg, Sungren \& Wells, 1998; Hermalin \& Weisbach, 1998, 2003). (Conger, Finegold \&Lawler 111; 1998) suggests that board that meets frequently signal board effectiveness.

Vafeas (1999) finds that it is inversely related to firm value, because of the increased board activities following share price declines. Abdullah, Ismail and Jamaluddin (2008) examined effective components of corporate governance in Malaysian listed companies and their: relationship with audit quality. A total of 655 companies were selected as: the sample; representing $73.84 \%$ of the total number of companies across. Industries in the year 2003. The analysis of logistic regression was used to investigate the relationship between dependent and independent variables. Their results showed that 2 independent variables had a significant relationship with audit firm size. The linkage between the board and the quality of audit activities done may be formal or informal. Farman and Jensen (1993) have observed that the board of directors is the best control mechanism to monitor actions of management. The study explored board independence based on the agency theory Studies of O'Sullivan (2000) and Salleh (2006) found that the proportion of non-executive directors had a significant positive impact on audit quality.

According to Wan, Shahnazi, \& Nurasyikiri (2008), the relationship between outside shareholders and managers is marked by circumstances and opportunism, which emanate from unequal distribution of information since the responsibility of financial reporting increases with the separation of ownership and control. Kane and Velury (2002) posit that the greater the level of the board independence, the more likely it is for firm to purchase audit services from large audit firm in order to ensure high audit quality. As it is applicable to auditors, so is it with the boards of an organization, they are expected to be independent. If there is a lack of board independence, it leads to board bias, lack of trust on the part of the workers and clients and eventually all fall in audit quality.

\section{The Research Methods and Materials}

Choosing the types of research method and materials technique are depends upon the area of research, research methodology, and preference of the researcher according to (Dawson, 2002)

\subsection{Description of Population of the Study}

The banking sector is one and the unique among all sectors of the economy in Ethiopia because it plays a central role in contributing to the financial stability of the economy and the provision of financial resources (NBE committee on banking supervision, 2013). There are 17 commercial banks in Ethiopia as at October 2010 EC and 15 banks for a period of 2004-2010 form the sample in this study.

\subsection{Sampling Techniques and Sample Size}

Two types of sampling techniques were employed by the researcher, namely, simple random sampling and stratified random sampling. The sample of 15 Commercial banks was chosen by simple random sampling technique. Simple random sampling techniques were used in the selection of the population. While stratified random technique was used in administering the questionnaires. Stratification contributes to sampling efficiency by lowering variances in the population. This is because using the stratified sampling method, we sample homogenous units.

\subsection{Sources of Data Collection}

Primary and secondary data were used to collect data needed for the research. The primary information was collected through the distribution of questionnaires and the secondary sources mostly annual reports and published journals.

\subsection{Method of Data Presentation}

To aid analysis and enhance understanding and comprehension on the part of the reading public, the data so collected will be presented in a tabular form. This method is chosen because of the simplicity and straight to the point posture.

\subsection{Method of Data Analysis}

For the purpose of this work, the following variables are considered relevant in the specification of our model and in examining the relationship between audit firm rotation and audit quality. The model was self-built and the functional form is given below.

$\mathrm{AQ}=\mathrm{bo}+\mathrm{b} 1 \mathrm{afr}+\mathrm{b} 2 \mathrm{af}+\mathrm{b} 3 \mathrm{cs}+\mathrm{b} 4 \mathrm{bi}+\mathrm{UT}$.

Where; $A Q=$ Audit Quality

$\mathrm{AFR}=$ Audit Firm Rotation 


$$
\begin{aligned}
& \mathrm{AF}=\text { Audit Fees } \\
& \mathrm{CS}=\text { Company Size } \\
& \mathrm{BI}=\text { Board Independence } \\
& \mathrm{U} 1=\text { Error term }
\end{aligned}
$$

The model prior Expectation is that B1, B3, and B4 $>0, \mathrm{~B} 2<0$

The model above is analyzed using the binary logic regression technique. According to Gauss-Markov theorem which states that if the underlying system linear with additive noise and the random variables representing the errors made by ordinary least square model are uncorrelated from each other and if the distributions of these random variables all have the same variance and a mean of zero, then the ordinary least squares method is the best unbiased linear estimator of the model coefficients. Furthermore, diagnostic test was carried out to determine the suitability of the use of the ordinary least method. Regression diagnostic is one of a set of procedures available for regression analysis that seek to assess the validity of a model in any of a number of different ways.

\section{Presentation of Data}

In this subsection, tables have been used to present the descriptive statistics, Pearson correlation, and binary logit regression result as estimated by using the STATA version 12

\subsection{Descriptive Statistics result}

For this research both descriptive and inferential statistical analysis is used as below

Table4.1 Descriptive Statistics of Variables

\begin{tabular}{|l|l|l|l|l|l|}
\hline & AQ & AFR & AF & BI & CS \\
\hline Mean & 0.971429 & 0.130794 & 89294.65 & 0.631514 & 7.887803 \\
\hline Std.Dev. & 0.167398 & 0.336005 & 67351.5 & 0.143167 & 1.044442 \\
\hline & & & & & \\
\hline Jarque-Bera & 4505.739 & 116.6509 & 97.20953 & 1.303548 & 16.99693 \\
\hline Probability & 0 & 0 & 0 & 0.52112 & 0.000204 \\
\hline Observations & 105 & 105 & 105 & 105 & 105 \\
\hline
\end{tabular}

Source: Researcher's Computation, 2018

According to descriptive analysis in the above table reveals that, the means of the independent variables, the mean value for audit firm rotation (AFR) is 13\%, company size (CS) is 7.89 while audit fees (AF) is Nearly 89295 . The mean value for audit fees reveals the average amount of money paid by the banks examined for audit services. BOD Independence stood at approximately $63 \%$. Thus, the BOD of the banks examined can be adjudged slightly independent since the mean value is slightly above $50 \%$. Based on the Jarque-Bera Statistics and associated probability, it is observed that all the variables examined except for BOD independence can be said to be normally distributed since all the probability values are lower than 0.05 which is the rule of thumb test for the normality of a distribution

Table 4.2: Pearson Correlation

\begin{tabular}{|l|l|l|l|l|l|}
\hline & AQ & AFR & AF & BI & CS \\
\hline AQ & 1 & -0.2748239 & 0.015252 & 0.043093 & -0.01201 \\
\hline AFR & -0.27482 & 1 & 0.17881 & -0.018 & -0.00622 \\
\hline AF & 0.015252 & 0.1788102 & 1 & -0.10058 & -0.01356 \\
\hline BI & 0.043093 & -0.0179983 & -0.10058 & 1 & 0.037346 \\
\hline CS & -0.01201 & -0.0062181 & -0.01356 & 0.037346 & 1 \\
\hline
\end{tabular}

Source: Researcher's Computation, 2018

Table 4.2 above shows the Pearson correlation of all examined variables for this study. The table shows that a 1-unit change in AQ is negatively related to approximately 0.27-unit change in AFR and to 0.012-unit change in $\mathrm{CS}$ while it is positively related to 0.015-unit change in AF and to 0.04-unit change in BI. Furthermore, all the independent variables have a weak relationship with AQ except for AFR, which has fair strong relationship. 


\subsection{Regression Estimation Result}

Table 4.3: Regression Result Extract

\begin{tabular}{|l|l|l|l|l|}
\hline Dependent variable: AQ & & & & \\
\hline Method: ML-Binary Logit Model & & & & \\
\hline Variable & Coeff & Std. Error & Z-Statistic & Prob \\
\hline C & 2.403127 & 6.232949 & 0.385552 & 0.6998 \\
\hline AFR & -3.19321 & 1.445779 & -2.20864 & 0.0272 \\
\hline AF & L.03E-05 & L.47E-05 & 0.699863 & 0.484 \\
\hline BI & 1.990916 & 4.067303 & 0.489493 & 0.6245 \\
\hline CS & 0.024323 & 0.616654 & 0.039444 & 0.9685 \\
\hline McFadden R-squared & 021152 & Mean depreciation variable & & 0.971429 \\
\hline LR statistic & 5.762989 & Total & & 105 \\
\hline Prob (LR statistic) & 0.217561 & & & \\
\hline
\end{tabular}

Source: Researcher's Computation, 2018

Table 4.3 is an extract of the regression result for the model as specified for this study. Based on the McFadden R-square, which reveals the combined explanatory effect of all the independent variables on the dependent, it is observed that all the independent variables can only account for about $21 \%$ of the systematic variation in the dependent variable leaving about $79 \%$ unaccounted for by variables not captured in the model. As regards the LR statistic and related probability value of 5.76 and 0.218 respectively, the overall significance of the model is poor as the probability value is greater than 0.05 . Thus, all the variables in the model when combined do not significantly affect audit quality.

With respect to the sign of the Z-statistics of the independent variables, only audit firm rotation (AFR) has a negative association with audit quality (AQ). All other independent variables have a positive association. Furthermore, based on the probability values of the Z-statistics of the independent variables, board independence (BI), audit fees (AF), and company size (CS) have an insignificant relationship with audit quality. However, audit firm rotation (AFR) has a significant relationship at the $5 \%$ level of significance.

\subsection{Hypothesis Testing}

For the purpose of better understanding, the hypotheses are restated and tested in this section. And for this study, the decision rule is to reject the null hypothesis and accept the alternative if the probability value of the t-statistics is less than 0.05 or accept the null and reject the alternative if the probability value is greater than 0.05 .

\section{Hypothesis One}

HO: Audit firm rotation contributes negatively to the quality of audit assignment.

HI: Audit firm rotation contributes positively to the quality of audit assignment.

With respect to the findings in table 4.3, the study concludes that audit firm rotation significantly negatively affect audit quality at $5 \%$ significance level as such, the null hypothesis is rejected. This finding is in line with the findings of Raiborn (2006), Cameron, Principe, Trumbo (2007). However, it negates the findings of, Chung (2004), Adeyemi and Okpala (2011).

\section{Hypothesis Two}

HO: There is no significant relationship between the firm's size and audit quality.

HI: There is significant relationship between the firm's size and audit quality.

It is observed from table 4.2.3 above that company size and audit quality have an insignificant positive relationship at $5 \%$ level of significance. Thus, this finding suggests that null hypothesis two should be accepted while the alternative is rejected. The finding there from is contrary to the findings by Adeyemi and Fagbemi (2010) but confirms the findings of Donovan (1997)

\section{Hypothesis Three}

HO: There is no significant relationship between board independence and audit quality.

HI: There is significant relationship between board independence and audit quality.

As regards the third hypothesis, the findings above show that audit fees do not significant affect audit quality at $5 \% \%$ level of significance Therefore, the null hypothesis is thus accepted. This finding is in line with the findings, however, it negates the findings of Arens and Loeb (1997), Ghosh and Pawlewich (2008).

\section{Hypothesis Four}

HO: There is no significant relationship between board independence and audit quality.

HI: There is significant relationship between board independence and audit quality.

With respect to the findings of this study as it relates to board independence and audit quality, the study concludes that there is an insignificant positive relationship between these two variables at 5\% significance level thus the null hypothesis is accepted. This finding is in line with the findings of Beasley, (1996), Dechow, Sloan and Sweeney (1996). However, it negates the findings of O'Sullivan (2000) and Saleh (2006), Kane and Velury (2002). 


\section{Summary of Findings}

The objective of this study is to evaluate the relationship between audit firm rotation and audit quality using a sample of 15 banks. The study attempted to provide empirical evidence of this relationship (if any) within the Ethiopian context. The findings that were gotten from the study were,

$\rightarrow$ Audit firm rotation significantly affect audit quality.

$\rightarrow$ There is no significant positive relationship between company size and audit quality.

$\rightarrow$ Audit fees does not significantly affect audit quality.

$\rightarrow$ There is no significant positive relationship between board independence and audit quality.

\subsection{Conclusion}

The debate on audit quality and audit firm rotation is not a settled matter. This study intended to assess the applicability of the mandatory auditor rotation concept in the Ethiopian banking sector so as to enhance and improve audit quality. The model introduced used different proxies such as audit fees, company size and board independence. It therefore concludes that rotation is a good solution to enhance and maintain the auditor independence by decreasing the audit firm's dependency on the client.

\subsection{Recommendations}

- From the findings of both the literature as well as the field study, the following are recommended. Regulatory bodies such as National Bank of Ethiopia and the Federal Auditor of General Office should help in making laws that will guide to audit firm rotation and improve audit quality.

- In addition, the National Bank of Ethiopia should also think possible other ways of enhancing audit quality.

- Concerning the audit fees, Federal General Auditor office should have to fix rate for certain auditor type.

- That the independence of the board of directors should be strengthened i.e. the composition of nonexecutive directors as members of the boards should be sustained and improved upon.

\section{References}

Audit Committee (2012). Wikipedia. Org. Retrieved from wiki/Audit committee.

Aziza, M., Monroe, G. \& Shailer, G. (2006). Auditors tenure \& perceived credibility of financial reporting. Australia: Australian National University.

Barbadillo, A. \& Aguilar, U. (2008). Does auditor tenure improve audit quality? Mandatory audit Rotation versus long term auditing: an empirical analysis. Working paper. University of Cadiz: Spain.

Basel Committee on banking supervision-consultative Document (2013). External Audits of Banks. Issued for comment 21 June. Retrieved from www.bis.org/publfbcbs 244.pdf.

Beasley, M. (1996). An empirical analysis of the relation between the board of director Composition and financial statement fraud. The Accounting Review 1(4), 443-465

Brody, R. G. \& Moscove, S.A (1998). Mandatory auditor rotation. Journal of National Public Accountant, 2(1), 32-36

Cadbury committee (1992) Report of the committee on the financial aspects of corporate Governance, London, Gee and Company Ltd.

Cameran, M., Prencipe, A. \& Trombetta, M.(2007). Earnings management, audit tenure, a Auditor changes. Milan: University Bocconi Printing Press.

Carcello, I \& Neal, T. (2000). Audit committee composition and auditor reporting. The Accounting Review, 75(4), 453-467.

Chung, H. (2004). Selective mandatory auditor rotation and audit quality and audit quality. An Empirical investigation of auditor designation policy in Korea, 2(3), 76-98.

Clarke, T. (2004). Theories of corporate governance. London: Routledge Taylor \& Francis Printers.

Conger, J. D, Finegold, G. \& Lawler, B. (1998). Appraising boardroom performance. Harvard Business Review. 76(1), 136-148.

Dalton, D. R., Daily, C.M, Johnson, J.L. \& Ellstrand, A.E. (1999). Number of directors and financial Performance: a meta- analysis. Academy of management Journal, 42(3), 674-686.

Davidson, C. (1993), Debating audit expectations in auditing, London: Paul Champion Printers.

Davis, L., Larry, R., Billy, S. \& Greg, T. (.2008). Auditor tenure and the ability to meet or beat earnings forecasts, Journal of Boston College, 2(3), 1-51.

Dechow, F. M., Sloan, R. G \& Sweeney, A. P. (1996). Causes and consequences of earning Manipulation: an analysis of firms subject to enforcement actions by the SEC, Contemporary Accounting Research, 13(1), 136.

Defond, M. \& Francis, J.R (2005). Audit research after Sarbanes-oxley. Auditing: A Journal of practice \& Theory, 
24(2), 5-30.

Donaldson, T. \& Preston, L. B. (1995). The stakeholder theory of the corporation: concepts, evidence and implications, Academy of Management Review, 20(1), 65-9 1.

Dopuch, N.D, King, R. \& Schwartz, R. (2001). An experimental investigation of reputation and Rotation and requirements. Journal of Accounting Research, 2(2), 23-31.

Durham University. Available at Durham E-thesis online http://etheses.dur.ac.uk/448/.

Dye, R. (1993). Auditing standards, legal liabilities and auditor wealth. Journal of Political Economy, 39(1),93117.

Ebimobowei, U. \& Oyadonghan, I. (2011). Mandatory rotation of auditors on audit quality. Retrieved from www.medwelljournal.com/fulltext/\%3...

Ebrahim, A. (2001). Audit quality tenure client importance and earnings management: an additional evidence. Retrieved from http://www.papers.ssrun.com/

Eisenberg, T.S., Sundgren, S. \& Well, M. (1998). Larger board size and decreasing firm value in small firms, Journal of financial economics, 48(1), 35-54.

Fama, E.K. \& Jensen, M.C. (1983). Separation of ownership and control, Journal of Law and Economics, 26(6), 301-325

Firth, M., Rui, M. O. \& Wu, X. (2010). Rotate back or not after mandatory. Hong Kong: Lingan University Press.

Francis, J. R. (2004). What do we know about audit quality? The British Accounting Review, 36(4), 345-368.

Freeman, R.E. (1984). Strategic management: A stakeholder approach. Boston: Pitman Publishers.

Freeman, R.E., Wicks, A.C. \& Parmar, B. (2004). Stakeholder theory and the corporate objective revisited. Journal of organization science, 15(3), 364-369.

Ghosh, A. \& Moon, D. (2005). Auditor tenure and perceptions of audit quality. The Accounting Review, 80(2), 585-612.

Habbash, M. (2010). The effectiveness of corporate governance and external audit on constraining earnings management practice in. UK: Doctoral thesis.

Healey, T.J. \& Kin, Y.J. (2003). The benefits of mandatory audit rotation regulations, Journal of audit, 26(3), 1012.

Hermalin, B. \& Weisbach, M. (1998). Endogenously chosen boards of directors and their monitoring of the CEO, American Economic Review, 88(2), 96-118.

Hermalin, B. \& Weisbach, M. (2003). Board of directors as an endogenously determined institution, Journal of the economic literature economic policy review, 12(4), 81-87.

Hoyle, J. (1978). Mandatory auditor rotation, the arguments and alternatives, Journal of Accountancy, 145(5), 6978.

Hyeeso, C. (2004). Selective mandatory auditor rotation and audit quality. Krannert: Purdue University Press.

Izedomi, F.O. \& Ogiedu, K.O. (2012). The potential effects of mandatory audit firm rotation: evidence from Ethiopia, International Journal Research in Commerce and Management, 12(2), 121-130.

Jackson, A.B., Moldrich, M. \& Roebuck, P. (2008). Mandatory audit firm rotation and audit quality, Managerial Auditing Journal, 23(5), 87-92.

Jekins, D.S. \& Velury, U. (2008). Does auditor tenure influence the reporting of conservative earnings? Journal of accounting and public policy, 27(2), 115-132.

Jensen, M. \& Meckling, W. (1976). Theory of the firm: managerial behaviour, agency costs and ownership structure. Journal of Financial Economics, 3(4), 305-360.

Johnson, V.E., Khurana, I.K. \& Reynolds, J.K. (2002). Audit firm tenure and the quality of financial reports, Contemporary Accounting Research, 19(4), 637-660.

Kane, J. \& Velury, O. (2002). The role of institutional ownership in the market of auditing services: an empirical investigation, Journal of Business Research, 4(8), 18 - 32.

Kiel, G. \& Nicholson, L. (2003). Board composition and corporate performance: how the Australian experience informs constraining, An International Review, 11(3), 76-80.

Knapp, M. (1991). Factors that audit committees use as surrogates for audit quality, Journal of Practice \& Theory, 10(1), 35-52.

Knechel, J. \& Vanstrelen, O. (2007). The relationship between auditor tenure and audit quality implied by going concern opinions, Journal of Practice and Theory, 26(1), 113-131.

Krishnan, J. (2005). Audit committee financial expertise and internal control: An empirical analysis. The Accounting Review 80(2), 649-675.

Levitt, A. (2000). Renewing the covenant with investors, New York: University centre.

Lu, T. (2005). Does opinion shopping impair auditor independence and audit quality? Journal of Accounting Research, 44(3), 561-583.

Mgbame, C.O., Eragbe, E. \& Osazuwa, N.P. (2012). Audit partner tenure and audit quality, an empirical analysis, European Journal of Business and Management, 4(7), 154-155. 
Millichamp, A.H. (1994). Auditing: an instructional manual for accounting students, Journal of accounting research, 6(1), $464-465$.

Mustafa, Z. (2009). Strengthening Small CPA Firms increasing Big CPA Firm, Journal of Accounting, 16(1), 2130.

Myres, J.N., Myres, L.A. \& Omer, C.T. (2003). Exploring the term of the auditor-client: the relationship and the quality of earnings: The Accounting Review, 78(3), 779-799.

O’Donova, G. (1997). Legitimacy theory and corporate environmental disclosure. Hobart Tasmania: Annual conference publication.

O'Sullivan, N. (2000). The impact of board composition and ownership on audit quality: evidence from large UK companies, the British Accounting Research, 34(4), 397-414.

Onwucheka, C.J., Erah, O. \& Izedomi, F. (2012). Mandatory audit rotation and audit quality: survey of southern Ethiopia, Research Journal of Finance and Accounting, 3(8), 70-71.

Palmrose, Z. (1986). Audit fees and auditor size: further evidence, Journal of Accounting Research, 24(1), 97-110.

Palmrose, Z. (1988). An analysis of auditor litigation and audit service quality, the Accounting Review, 63(2), 5573.

Raiborn, J. Cecily, C.A. Schorg, J. \& Morcos, M. (2006). Should auditor rotation be mandatory? The Journal of Corporate Accounting and Finance, 2(1), 37-49.

Reynolds, J.K. \& Francis, J.R. (2000). Does mandatory rotation enhance auditor independence? European Accounting Review, 9(2), 205-224.

Rita, Y. (2011). Audit firm size, audit fee and audit quality, Journal of Global Management, 2(1), 87-91.

Riyatno, G. (2007). Public accounting firm size effect on earnings response coefficients, Journal of Financial and Business, 5(2), 70-81.

Securities and Exchange Commission (2003). Final rule: strengthening the commission's requirements regarding auditor independence, Washington: Government: printing press.

Selleh, Z., Stewart, J. \& Manson, S. (2006). The impact of board composition and ethnicity on audit quality: evidence from Malaysian companies, Malaysian Accounting Review, 5(2), 61-83.

Semiu, B.A. \& Temitope, O. F. (2010). Audit quality, corporate governance and firm characteristics in Ethiopia, International Journal of Business Management, 5(5), 170-171.

Vafeas, N. (1991). Board meeting frequency and firm performance, Journal of Financial Economics, 53(2), 113142.

Wallace, W. (1980). The economic role of the audit in free and regulated markets. Touché: Ross Teaching Press.

Wan, Z.W.A., Shahnazi, I. \& Nurasyikiri, J. (2008). The impact of board composition: ownership and CEO duality on audit quality, Malaysian Accounting Review, 7(2), 1-22.

Watts, R. \& Zimmerman, J. (1981). The markets for independent auditors, New York: University of Rochester Press.

Weber, J., Wallenberg, M. \& Zhang, J. (2008). Does auditor reputation matter? The case of KPMG Germany and Comroad, Journal of Auditing, 6(4), 65-69.

Wolf, J., Fran, M., James, A. J. \& Gregory, A.C. (1999). Audit disaster future: antidotes for the expectation gap, Managerial Auditing Journal, 14(9), 468-469.

Xie, B., Davidson, W. \& Dadalt, P. (2003). Earnings management and corporate governance: the role of the board and the audit committee, Journal of Corporate Finance, 9(2), 295-316.

Yermack, D. (1996). Higher market valuation of companies with a small board of directors. Journal of Financial Economics, 40(2), 185-212. 